snakes in the Georgics. Keeping company as it does with the glorious rose gardens of Paestum and the elegant, watery endive and celery, the plump cucumber thus adds to the sense that a garden has the potential to surprise with its bounty. For an instant reminding us of the sinister snakes lurking in the grass elsewhere in the Georgics, the cucumber emerges as a harmless, and welcome, vegetable.

The reader is left with a multi-layered cucumber: it is there, simply, as much-loved garden produce; there, symbolically, as a reminder of nature's (and the poem's) dark and light side; there, academically, as an allusion to a cucumber of a particular variety and to one of Virgil's scientific sources.

For a postscript on Virgil's cucumber, I turn to Propertius, whose Vertumnus also mentions the vegetable, in a line often cited by commentators as a parallel: caeruleus cucumis tumidoque cucurbita uentre (4.2.43). Here the cucumber appears alongside its natural partner, the gourd, and it is the gourd that is described as having a fat belly. ${ }^{9}$ Might Propertius be engaging in a gentle 'correction' here, arguing that the gourd better deserves to be called fat than its slimmer counterpart the cucumber? ${ }^{10}$

St Hilda's College, Oxford

REBECCA ARMSTRONG

rebecca.armstrong@st-hildas.ox.ac.uk doi:10.1017/S0009838808000402

\begin{abstract}
${ }^{9}$ It should be acknowledged that opinions differ about how to translate cucumis; I am going (amongst many others) with the $O L D$ definition, cucumber. For those who think of it as a type of gourd, this interpretation of Propertius' lines may not appeal. As is often the case when attempting to distinguish very similar types of plant in ancient sources, absolute certainty can be hard to achieve. Modern botanists class all cucumbers, melons, gourds and marrows among the Cucurbitaceae, the cucumber being Cucumis satiuus, the melon Cucumis melo, the squash Cucurbita maxima or moschata, and so on.

10 G.O. Hutchinson, Propertius Elegies Book IV (Cambridge, 2006), ad Prop. 4.2.43-4 suggests a further comment on size here, as Vertumnus squeezes more vegetables into his garden than Virgil.
\end{abstract}

\title{
AUGUSTUS AND ORESTES: TWO LITERARY CLUES*
}

Over the last two decades, several studies have touched upon potential links between the self-presentation of Augustus and the myth of Orestes. ${ }^{1}$ The parallels open to exploitation in this context are obvious: Orestes' father was murdered by his unfaithful mother Clytemnestra and her lover Aegisthus. The assassination of Augustus' legal father Caesar could be attributed to the anticaesarian party as a

* I should like to thank Martin Korenjak and the anonymous referee for their helpful suggestions, as well as Yvona Trnka-Amrhein for correcting my English.

1 The most important and inclusive is T. Hölscher, 'Augustus and Orestes', Travaux du Centre d'archéologie méditerranéenne de l'Académie Polonaise des sciences 30, Études et Travaux 15 (1990), 163-8; cf. further M. Dewar, 'Octavian and Orestes in the finale of the first Georgic', $C Q$ 38 (1988), 563-5; 'Octavian and Orestes again', CQ 40 (1990), 580-2; A. Delcourt, 'Entre légende et histoire: Oreste et le prince', LEC 66 (1998), 61-72; E. Champlin, 'Agamemnon at Rome: Roman dynasts and Greek heroes', in D. Braund and C. Gill (edd.), Myth, History and Culture in Republican Rome: Studies in Honour of T.P. Wiseman (Exeter, 2003), 295-319, at 308-10. 
whole, whose particular exponents at Actium were Antonius ('Aegisthus') and Cleopatra ('Clytemnestra'). By killing Aegisthus and Clytemnestra, Orestes became the archetypical avenger of classical antiquity. Augustus readily cast himself in the role of the avenger, which played an important part in his ideological programme ${ }^{2}$ according to which the horrors of the civil war were brought to rest by one last act of just revenge. Similarly, Orestes' feat ended the mutual bloodshed in the house of Atreus. At least in the predominantly optimistic versions of his myth, as exemplarily codified in Aeschylus' Eumenides, Orestes was cleared from charges in the end - a circumstance which must have appealed to Augustus' efforts to erase the memory of his own cruelties. Finally, the mythical hero was assisted throughout his trials by Apollo - the same Apollo that Augustus chose as his tutelary god. T. Hölscher has adduced some significant art historical examples to support his hypothesis that these correspondences played a part in Augustan self-presentation. ${ }^{3}$ I would like to add two literary clues not hitherto discussed. There may be some more allusions to Augustus and Orestes in assorted accounts of the prominent cult of 'Orestean Diana' (cf. Ov. Met. 15.489.: sacraque Oresteae...Dianae) in the Latian town Aricia. However, I will not discuss these here because they appear to be unclear and a good deal of interpretation would be needed to argue for them. ${ }^{4}$ My two nuggets will be comparatively straightforward.

The first of these brings us to the time immediately following Caesar's assassination and into the midst of the political situation in which the identification of Augustus with Orestes would have started to develop. Suetonius reports that at the celebrations arranged for Caesar's funeral, passages from tragedies were sung in order to arouse pity for Caesar and hatred for his murderers. Among them was the Electra of Atilius, a play which Cicero claimed to be a conversio of Sophocles' piece. ${ }^{5}$ It is certainly not accidental that a tragedy based on the Sophoclean model was picked for the occasion. In Sophocles' Electra, the justice of Orestes' revenge is never questioned. By killing his odious opponents, Orestes liberates the house of Atreus and the play ends on a note of cheerful triumph. ${ }^{6}$ At the time of Caesar's death and before Octavian's warfare against his enemies, the drama must have conveyed a clear

${ }^{2}$ Conspicuously reflected e.g. in the erection of the temple of Mars Ultor in the Forum of Augustus; cf. further $R G$ 2: qui parentem meum trucidaverunt, eos in exilium expuli iudiciis legitimis ultus eorum facinus et postea bellum inferentis rei publicae vici bis acie; Ov. Met. 15.818-21 (Jupiter comforts Venus on the inevitable murder of Caesar): ut deus accedat caelo templisque colatur, I tu facies natusque suus: qui nominis heres / inpositum feret unus onus caesique parentis / nos in bella suos fortissimus ultor habebit. See Bömer's commentary ad. loc. for further reading on Augustus' ideology of ultio.

3 These include: a statue of Orestes in front of the Heraeum near Mycenae which according to Paus. 2.17.3 was reworked into one of Augustus; a relief from the Villa Medici which possibly shows the transfer of Orestes' bones from his Italian sanctuary at Aricia to Rome; a supposedly archaising relief from Aricia depicting Orestes as an avenger, maybe dating from the Augustan period; a relief from Naples on which Orestes confidently sets out (to Athens?) while the Erinyes are sleeping.

${ }^{4}$ See now C. Green, Roman Religion and the Cult of Diana at Aricia (Oxford, 2007), esp. 208-31.

5 Suet. Iul. 84.2: inter ludos cantata sunt quaedam ad miserationem et invidiam caedis eius accommodata, ex Pacuvi Armorum iudicio: men servasse, ut essent qui me perderent? et ex Electra Acili ad similem sententiam. - Cic. Fin. 1.5: A quibus tantum dissentio, ut, cum Sophocles vel optime scripserit Electram, tamen male conversam Atilii mihi legendam putem.

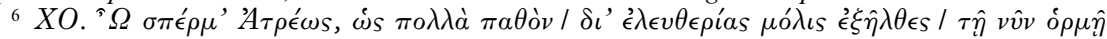
$\tau \epsilon \lambda \epsilon \omega \theta \epsilon^{\prime} \nu$. Of course the notion of $\epsilon \lambda \epsilon v \theta \epsilon \rho i ́ \alpha /$ libertas would have fitted Augustan self-presentation as well, see R. Syme, The Roman Revolution (Oxford, 1939), 155. 
exhortative message of revenge. So, it would have cast Octavian in the role of the avenger even before this identification became useful as an excuse for an uncomfortable past.

A second passage seems to suggest that the myth of Orestes was one of Augustus' personal favourites. Although a product of the later days of Augustus' principate, it points to a rather general disposition. I refer to Tristia 2, Ovid's lengthy letter of apology and plea to the Princeps. As part of his excuse for the apparently indecent carmen (207), mentioned as one of the reasons for Augustus' displeasure, the author adduces a series of examples of eroticism in literary history, and thereby implies that hardly any literature can be written without erotic motives (361-470). In this extended catalogue, authors and works are never introduced in a way that would present Augustus as an actual reader except for the verses 395-6: qui legis Electran et egentem mentis Oresten, I Aegisthi crimen Tyndaridosque legis. Much more hypothetical (because of the future tense and the semantics of invenio) is the only other comparable verse in this respect: invenies eadem blandi praecepta Properti (465). Of course, given the grammar, both passages could address a general second person ('if one reads...', 'People will find...'). Still, in a letter addressed to Augustus and in a context in which he is the one to be convinced by the enumeration of authors and works, this would not be the natural reading.

Universität Bern

STEFAN TILG

stefan.tilg@kps.unibe.ch doi:10.1017/S0009838808000414

\section{A VAGINA IN SEARCH OF AN AUTHOR}

Poetic descriptions of the vagina, its physical features and its excellence as a route to delight, are, I surmise, infrequent in the writings of bishops. It is a piquant surprise to find one lurking in Hippolytus' Refutation of All Heresies (if indeed the work is his). In a passage concerned to show that Gnostic doctrines are derived from the Greek mysteries (5.8.41-5), the Greater Mysteries (those of Demeter) are taken to stand for

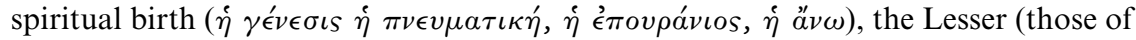
Persephone) for that of the flesh ( $\tau \dot{\alpha} \tau \hat{\eta} s \sigma \alpha \rho \kappa \iota \kappa \hat{\eta} s \gamma \epsilon \nu \epsilon \in \sigma \epsilon s)$ :

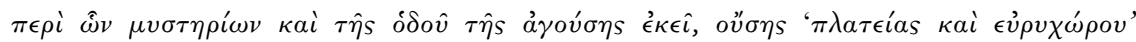

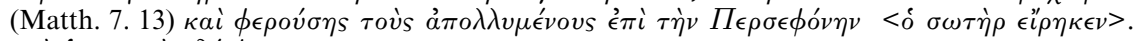

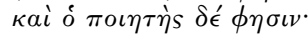

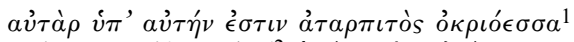

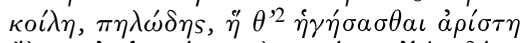

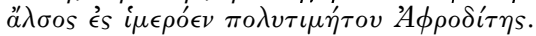

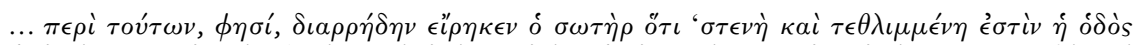

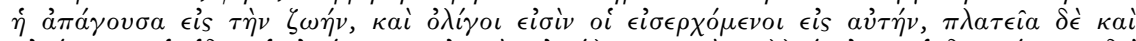

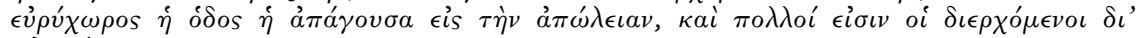
aủं $\hat{\eta} s^{\prime}$ (Matth. 7. 13-14, inaccurately).

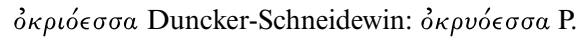

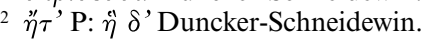

